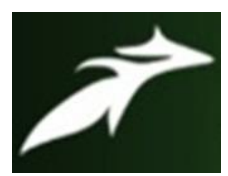

Ashish Anand et al, International Journal of Advances in Agricultural Science and Technology, Vol.8 Issue.8, August-2021, pg. 170-177

ISSN: 2348-1358

Impact Factor: 6.057

NAAS Rating: 3.77

\title{
ASSOCIATION BETWEEN SOCIO-ECONOMIC CONDITION AND KNOWLEDGE LEVEL OF INDIGENOUS TECHNICAL KNOWLEDGE (ITK) BY RURAL FARM FAMILIES IN SAMPATCHAK BLOCK IN PATNA DISTRICT OF BIHAR
}

\author{
Ashish Anand* \\ M.Sc Ag. (Agricultural Extension and Communication), SHUATS (Prayagraj) \\ Syed H. Mazhar** \\ (Associate Professor) Department of Agriculture Extension and Communication, SHUATS (Prayagraj) \\ Jahanara $* * *$ \\ Head, Department of Agriculture Extension and Communication, SHUATS (Prayagraj) \\ Dipak Kumar Bose**** \\ (Associate Professor) Department of Agriculture Extension and Communication, SHUATS (Prayagraj) \\ Department of Agriculture Extension and Communication, SHUATS (Prayagraj) \\ *Email id: aaiduashish@ gmail.com \\ DOI: 10.47856/ijaast.2021.v08i8.018
}

\begin{abstract}
The present study was conducted in Patna District of Bihar to find out the association between socio-economic condition and knowledge level of rural farm families regarding indigenous technical knowledge. A total of 120 respondents were selected randomly for the present study. The data were collected through a pre-structured interview schedule and appropriate statistical analysis was done to find out the association. It was found that age, mass media exposure and extension contacts were found to be highly significant with relation to knowledge of the rural farm families regarding indigenous technical knowledge whereas land holding was found to be mildly related.
\end{abstract}

Keywords: Indigenous Technical Knowledge, rural farm families

\section{Introduction-}

The paradigm shift of Indian agriculture from traditional to sustainable agriculture has developed a concept that focuses on producing crops and livestock while having minimal effects on the environment, helping in maintaining economic stability of farms and helping farmers improve their techniques and quality of life. This in return, has evoked interest among farmers in adopting indigenous technical knowledge, that utilizes local knowledge, which people have gained through inheritance from their ancestors, to solve problems pertaining to agriculture and allied activities through natural processes. The advent of the concept of sustainable agriculture in late eighties in Indian agricultural scenario has evoked interest on indigenous technical knowledge 


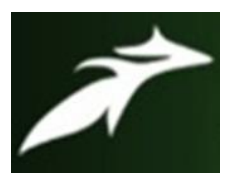

Ashish Anand et al, International Journal of Advances in Agricultural Science and Technology,

Vol.8 Issue.8, August-2021, pg. 170-177

ISSN: 2348-1358

Impact Factor: 6.057

NAAS Rating: 3.77

(ITK) that has the element of use of natural products to solve the problems pertaining to agriculture and allied activities. ITK is local knowledge that is unique to a given culture or society transmitted from one generation to another generation. It is specifically concerned with actual application of the thinking of the local people in various operations of agriculture and allied areas. ITKs are based on experiences tested over centuries, and endowed with best adaptability to local environment. In the context of agricultural sustainability.

At the onset of the 21 st century, the world faces a tremendous diversity of global challenges. On the developmental front one of these challenges is of institutionalization of sustainability. In the context of agricultural development, a new agenda has come up for achieving the objectives of generation and dissemination of economically feasible, socially acceptable and environmentally sound technologies that refers to the locality. Indian farmer has their deep roots in knowing what works in their farms, even local agricultural schools cannot teach such knowledge because of its vast extent and its wide range of variations (Pereira, 1993). Developing countries like India have a reservoir of indigenous knowledge which may certainly prove to be more valuable to all of us in reorganization of our developmental efforts towards nation's self-sufficiency.

Being an agriculture dependent country, in India, our developmental efforts are concentrated around transforming traditional agriculture technology to a way to modern technology but the potentiality of traditional agriculture is increasingly being recognized during last few years. "Developing countries have a valuable but largely untapped reservoir of indigenous agricultural knowledge." (Warren, 1993).Knowledge or experiences have been passed on from one generation to another by word of mouth, which are commonly known as "Traditional Agricultural Practices." The term "Indigenous" is often interchangeably used with "Traditional" or "Local" (Chithraichelvan, 1994)

The word "Traditional" implies the sense of tradition and tradition derived the word "Tradere" means "to transmit". In this respect we can say that tradition is transmission of community values and behaviour which is rooted in the past. Old traditions are always replaced by new traditions due to some external and internal factors. In this sense, tradition is not static, it has dynamic nature. Traditional agricultural knowledge is generated by the local people with their own experiences and experimentation to meet their needs and which is sustainable. This knowledge is tightly interwoven with their beliefs, norms and culture so that it could maintain its identity. Traditional agricultural knowledge has several characteristics like it has minimum risk 


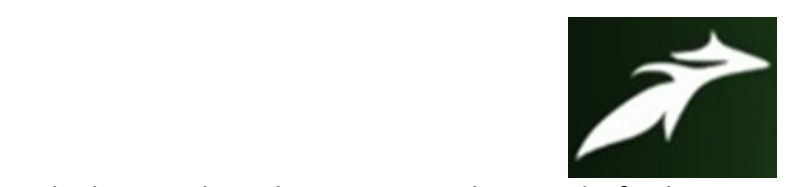

Ashish Anand et al, International Journal of Advances in Agricultural Science and Technology,

Vol.8 Issue.8, August-2021, pg. 170-177

ISSN: 2348-1358

Impact Factor: 6.057

NAAS Rating: 3.77

factor; heavy reliance on genetic and physical diversity; exploits optimum utilization of local resources; environmentally healthy; readily available and easily understandable.

Various socio-economic factors might also affect the knowledge possessed by rural farm families regarding ITK. The association was also studied. Further it is labor intensive, fits into local farming system and adaptable to meet multipurpose community needs, based on cultural values

of the community; is attested by evidence from trustworthy sources and had good culinary qualities. Farmers would be happy and proud to be recognized as custodians of their own knowledge, be partners of development initiatives and be empowered by their own resources, institutions and skills.

\section{Research Methodology-}

The present study was conducted in Patna district of the Bihar state. They prominently and actively participate in various farming activities and contribute in their household economy. There are 23 blocks functioning in the District. Sampatchak block was selected by purposive sampling for the research due to more number of ITK users as per pilot survey. There are 47 villages in Sampatchak Block. Out of these, 10 villages were selected purposively based on maximum number of ITK users for the present study.

From the 10 villages, 120 respondents were selected randomly. A structured interview schedule was used for data collection. Descriptive research design was used for this study. The statistical tools such as frequency, percentage and chi-square test, correlation coefficient were used to interpret the data and for drawing logical conclusion.

\section{Results and Discussion-}

Traditional wisdom is the rich store house of knowledge, for sustainable development. There is need to systemically analyze such rich knowledge resources of local farmers. The technologies are generally delivered by extension functionaries on the basis of what the research stations have handed over to them. Such technologies which are developed in a rapidly advancing society might have limited application in the local areas. Hence, this investigation helped to bring in to limelight the hidden knowledge used by local people since generations and in solving the problems of people in the area of agriculture. 


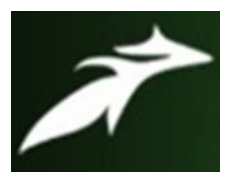

Ashish Anand et al, International Journal of Advances in Agricultural Science and Technology, Vol.8 Issue.8, August-2021, pg. 170-177

ISSN: 2348-1358

Impact Factor: 6.057

NAAS Rating: 3.77

Table 1 Socio-economic profile of the respondents:

$$
\mathrm{N}=120
$$

\begin{tabular}{|c|c|c|c|c|}
\hline S.No & Independent variables & Category & Frequency & Percentage \\
\hline \multirow{3}{*}{1.} & \multirow{3}{*}{ Age } & Young (18-35) & 10 & 8.34 \\
\hline & & Middle (36-55) & 57 & 47.50 \\
\hline & & Old (above 55) & 53 & 44.16 \\
\hline \multirow{6}{*}{2.} & \multirow{6}{*}{ Education } & Illiterate & 22 & 18.34 \\
\hline & & Primary School & 18 & 15.00 \\
\hline & & Upper primary & 35 & 29.16 \\
\hline & & Secondary & 20 & 16.66 \\
\hline & & Higher Secondary & 16 & 13.34 \\
\hline & & Graduation and above & 09 & 7.50 \\
\hline \multirow{3}{*}{3.} & \multirow{3}{*}{ Caste } & General & 42 & 35.00 \\
\hline & & OBC & 48 & 40.00 \\
\hline & & $\mathrm{SC}$ & 30 & 25.00 \\
\hline \multirow{4}{*}{3.} & \multirow{4}{*}{ Land holding } & Below 1 acre & 22 & 18.33 \\
\hline & & $1-2$ acre & 84 & 70.00 \\
\hline & & $2-3$ acre & 12 & 10.00 \\
\hline & & Above 3 acre & 02 & 1.67 \\
\hline & & & & \\
\hline
\end{tabular}




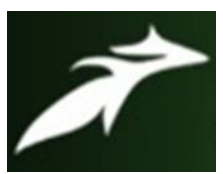

Ashish Anand et al, International Journal of Advances in Agricultural Science and Technology, Vol.8 Issue.8, August-2021, pg. 170-177

ISSN: 2348-1358

Impact Factor: 6.057

NAAS Rating: 3.77

\begin{tabular}{|c|c|c|c|c|}
\hline \multirow[t]{3}{*}{4.} & \multirow[t]{3}{*}{ Annual income } & Less than Rs. 75,000 & 36 & 30.00 \\
\hline & & Rs.75,001- 2 lakh & 78 & 65.00 \\
\hline & & Above Rs. 2 lakh & 06 & 5.00 \\
\hline \multirow{3}{*}{5 . } & \multirow{3}{*}{ Family size } & Upto 5 & 62 & 51.67 \\
\hline & & $5-10$ & 52 & 43.33 \\
\hline & & Above 10 & 06 & 5.00 \\
\hline \multirow{3}{*}{6.} & \multirow{3}{*}{ Mass media exposure } & Low(4-5) & 22 & 18.34 \\
\hline & & Medium(5.1-6) & 64 & 53.33 \\
\hline & & $\operatorname{High}(6.1-7)$ & 34 & 28.33 \\
\hline \multirow{3}{*}{7.} & \multirow[t]{3}{*}{ Extension contacts } & $\operatorname{Low}(6-7)$ & 20 & 16.67 \\
\hline & & Medium(7.1-8) & 64 & 53.33 \\
\hline & & $\operatorname{High}(8.1-9)$ & 30 & 25.00 \\
\hline
\end{tabular}

From the table 1, it was concluded that 47.50 per cent of the respondents belonged to the age group of 36-55 years i.e. middle age, 29.16 per cent of the respondents were educated up to upper primary. In terms of caste, 40 per cent of the respondents were OBC. Majority of the respondents i.e. 70 per cent had 1-2 acres of land.65 per cent of the respondents earned an annual income of 75,000 to 2 lakh. 51.67 per cent of the respondents had family size upto 5 members.53.33 per cent of the respondents had medium level of mass media exposure.53.33 per cent of the respondents had medium level of extension contacts. Similar findings was reported in case of Rao (1996) and Rambabu (1997). 


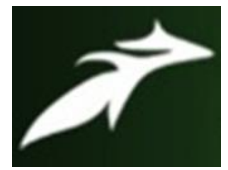

Ashish Anand et al, International Journal of Advances in Agricultural Science and Technology, Vol.8 Issue.8, August-2021, pg. 170-177

ISSN: 2348-1358

Impact Factor: 6.057

NAAS Rating: 3.77

\section{Association between selected independent variables with similar knowledge level}

Table 2- Association between selected independent variables with similar knowledge level of respondents in ITK:

\begin{tabular}{|c|c|c|}
\hline Sl. No. & Variables & Correlation coefficient value \\
\hline 1 & Age & $0.99(\mathrm{HS})$ \\
\hline 2 & Education & $0.15(\mathrm{NS})$ \\
\hline 3 & Caste & $-0.03(\mathrm{NS})$ \\
\hline 4 & Land holding & $0.45(\mathrm{MS})$ \\
\hline 5 & Annual income & $0.24(\mathrm{NS})$ \\
\hline 6 & Family size & $-0.51(\mathrm{NS})$ \\
\hline 7 & Mass media & $0.81(\mathrm{HS})$ \\
\hline 8 & Exposure & $0.83(\mathrm{HS})$ \\
\hline
\end{tabular}

-NS- Non-significant-MS-Mildly significant -HS-Highly significant

From the above data it was concluded that age, mass media exposure and extension contact are highly significant with knowledge of respondents regarding ITK .land holding was found to be mildly significant. Education, caste, annual income and family size are nonsignificant with knowledge. Similar findings were reported in case of Sharma(1993).

\section{CONCLUSION-}

Thus it was concluded that most of the respondents were middle aged, were educated up to upper primary. Majority of the respondent had small land holding. Most of them had nuclear family and had medium level of mass media exposure and extension contacts. Mass media 


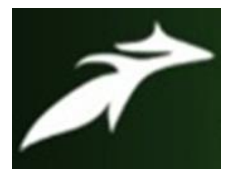

Ashish Anand et al, International Journal of Advances in Agricultural Science and Technology,

Vol.8 Issue.8, August-2021, pg. 170-177

ISSN: 2348-1358

Impact Factor: 6.057

NAAS Rating: 3.77

exposure and extension contacts was found to be highly related with knowledge of the respondents regarding ITK. While land holding was mildly related and education, caste, annual income and family size was found to be unrelated to knowledge of the respondents towards ITK.

\section{REFERENCES}

[1]. Altieri, M.A. and Merrick, L.C. (1987). In situ conservation of crop genetic resources through maintenance of traditional farming systems. Economic Botany 41(1): 86-96

[2]. Ambulkar, R.R. (1996). Evaluation of agricultural and rural development activities of Non-Government organization in Wardha district. M.Sc. Thesis, Punjab Rao Krishi Vidyapeeth, Akola.

[3]. Attee, D. (1989). Indigenous local knowledge as a key to local level development. Unpublished paper, DCR bulletin, 74, March: 11.

[4]. Bajpai, N. (1987). A study of attitude of farmers towards Minikit demonstration programme - sponsored by IFFCO in Jaipur district of Rajasthan. M.Sc. (Ag.) Thesis, SKN college of agriculture, Jobner, RAU, Bikaner.

[5]. Bakshi, B. (1969). Differential acceptance of alkathene storage bin as related to levels of exposures and socio-economic characteristics of the farmers in Kanjhawala block. M.Sc. (Ag.) Thesis, IARI, New Delhi.

[6]. Balasubramaniam, P. (1992). Indigenous knowledge use in dry lands - an exploratory study. M. Sc. (Ag.) Thesis, Tamil Nadu Agricultural University, Coimbatore.

[7]. Chitraichelvan R. (1994) Use of ITK in farming system research Proceedings of international workshop on genetic resources , UPWARD,LOS Banos Phillipines

[8]. Kalidasan,T.(2019).International journal of Innovative Technology and Exploring Engineering,vol-9 issue-2,Tamilnadu.

[9]. Kumar,S.(2018). Constraints Faced by Farmers in Adoption of Indigenous Technical Knowledge Associated with Indigenous Cattle Dairy Farming in Rajasthan,NDRI.

[10].Naharki,K.(2020).Documentation of Indigenous technical knowledge and their application in pest management in western mid of Nepal.

[11].Pereira,W . (1993). Trending the Earth Earth care books , Bombay : 135-134

[12].Quader,A.(2018).Farmer's willingness to use innovative indigenous technical knowledge for plant protection in major zones of Bangladesh,Commilla district,Bangladesh.

[13]. Rambabu p. (1997) Indegenous technologies in cropping system-an analytical study in Guntur district of Andhra Pradesh

[14].Rao D Koteshwar (1996) An analytical study on participation of chechu triabls in their agriculture

[15].Sharma , R.N (1993). Attitude of beneficiaries towards jawahar rojgaar yojana in Jamwa-Ramgarh of Jaipur district . Msc.(Ag) Thesis, SKN college of agriculture,Jobner ,RAU

[16].Sikutshwa,L.(2020).Acknowledging Indigenous and local knowledge to facilitate collaboration in Landscape approaches. 


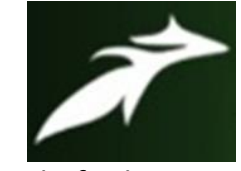

Ashish Anand et al, International Journal of Advances in Agricultural Science and Technology,

Vol.8 Issue.8, August-2021, pg. 170-177

ISSN: $2348-1358$

Impact Factor: 6.057

NAAS Rating: 3.77

[17].Singh, P.(2013). Indigenous Technical Knowledge (ITK) and their Role in Sustainable Grassroots Innovations: An Illustration in Indian Context,University of Delhi,Delhi.

[18].Tyagi,S.(2018).Conservation and managememt of Indigenous Technical Knowledge for livelihood upliftment of small and marginal farmers in rural areas, International Journal of Inclusive Development, Citation:4(2),53-58, Chattisgarh.

[19].Warren, D. M. (1993). Indigenous knowledge and development monitor. CIKARD I(1):7. 